Donato De Gianni

\title{
Four Variations on the Theme
}

\author{
"The Withered Fig Tree" (Mt 21.17-22; Mc 11.12-14. 20-25) in \\ Juvencus, Sedulius, Avitus of Vienne and Severus of Malaga(?)*
}

\section{Introduction}

Among the narratives that appear in succession in the Gospels, the episode of the barren fig tree cursed ${ }^{1}$ by the Lord has raised a wide set of different exegetic problems, both to ancient and modern critics, due to some peculiar features, which were already considered absurd by Theophylact ${ }^{2}$. Leaving aside the analogies with the parable of the fig tree in the vineyard found in Luke 13.6-9, which must be placed in a completely different context and implicates a different symbolic significance $^{3}$, the versions found in Mc 11.12-14 and Mt 21.17-22 are the only known biblical records of this miracle. In the version of Mark, the episode, which is split into two segments and frames the narrative of the cleansing of the temple (verses 15-19), closes with a parenetic speech of Christ about the power of faith and prayer, which may seem incongruous with the sequence of the events, or even cryptic, despite its internal logic and coherence. Although, in a more concise form and completely embedded in the main narrative, this dialogic addition is also found in Matthew, in the shape of an immediate back and forth between Jesus and the disciples

\footnotetext{
* All translations are mine, unless otherwise indicated.

1 The denomination commonly used to designate the episode is only deduced from the words of

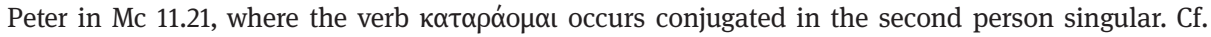
Pesch (1980 - 82) 295.

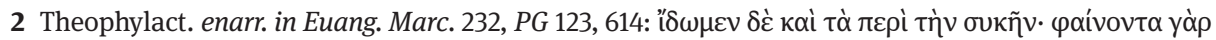

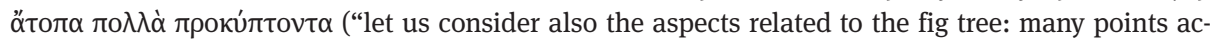
tually emerge that seem to be absurd"). Modern scholars have critically commented especially on Jesus' excessive strictness in punishing the tree and, in general, on the questions regarding the literary form of the evangelical passage, starting from the methodological approaches of the Formgeschichte and of the Redaktiongeschichte. For on of the most interesting contributions on the topic see Biguzzi (1987) 55. Original and thoroughly conducted is the recent analysis of the pericope by Grosso (2004) 121-147.

3 In the field of the scriptures, the symbolic connotations assumed by the fig tree are varied: Nathanael is identified as an Israelite through a reference to the fig tree in Ioh 1.48; elsewhere, its leaves forecast the summer (Mc 13.28); in the Old Testament tradition the fig tree is often associated with the concepts of peace and salvation (Mich 4.5; Zacch 3.10; I Macc 14.12). A broad discussion of the significance of the fig tree in classical and Christian sources, both biblical and patristic, can be found in Reichmann (1969) 640-689.
} 
about the immediate withering of the tree (verses 20 -22). The overall structure of the narrative is summarised in the following diagram:

Jesus' hunger

He approaches the tree and does not find any fruits

Because it was not the season for figs

Curses
Mc 11.12; Mt 21.18

Mc 11.13; Mt 21.19

Mc 11.13

Mc 11.14; Mt 21.19

Inserted into this common structure, which is - taking also into account that the above-mentioned parallel of Luke's narrative is based on the same plot outline deeply rooted in tradition, are grafted elements that significantly differentiate the two versions. The most obvious among these elements is certainly the passage found in Mark which generally translates as follows: "for the time of figs was not yet". This passage has been the object of botanical ${ }^{4}$ and allegorical conjectures since the time of the Church Fathers and is still the object of interpretative hypotheses of New Testament critics, who, however, tend to see in this paradoxical sentence the real expressive power of the narrative ${ }^{5}$. Thus, it is easy to understand its fruitful reception even among Christian poets, who rendered its plot in verses.

In the framework of the general debate about biblical paraphrasis that has taken place in the last 40 years ${ }^{6}$, the four most complete poetic retractationes of this New Testament passage ${ }^{7}$, realised in late antiquity by Juvencus, Sedulius, Avitus and Severus of Malaga(?) $)^{8}$, will be discussed in this paper. Similarities and differences in comparison with the narratological characteristics of the original narrative will emerge, as well as possible exegetical and theological additions, comprehensible

4 The pericope of Mark's Gospel has recently been re-examined, with new methodological approaches, by Oakman (2008) 184-186, whose interpretative proposal is originated by socio-economic premises, concerning the expropriation of farmers' lands through taxes and an accumulation of debts by the élites of the first-century Palestine, with subsequent repercussions on the agricultural production. The fig tree wood was specifically intended for sacrifices in the temple; thus, the barrenness of the fig tree would symbolically show the passage to this new agricultural and economic Palestinian system, condemned (cursed) by Jesus.

5 Some scholars have considered this aside a gloss, preceding or following the final redaction merged into the text: Hatch (1923) 6-12; Manson (1950 - 51) 271-281; Smith (1960) 326-327; some others, with grammatical stretches, have suggested to read the whole expression as an interrogative clause: Romaniuk (1975) 277-278. However, the sentence is unanimously attested by the tradition and with valid arguments defended by Grosso (2004) 123-124.

6 Among the most relevant studies are Kartschoke (1975); Herzog (1975); Kirsch (1979) 38-53; McClure (1981) 305-321; Roberts (1985); Nodes (1993); Deproost (1997) 14-39; Nazzaro (2001) 119153; Nazzaro (2006) 397-439; Dinkova-Bruun (2007) 315-342.

7 The passages from Mark and Matthew are cited according to the text of the Vetus Latina, which most probably Juvencus, too, had at hand: Jülicher (1938) 150 -151 and Jülicher (1940) 103-106. Possible comparisons with the Vulgata, which has been used by later authors, are made on the basis of the edition of Weber-Gryson $\left(2007^{5}\right)$.

8 The following critical editions have been consulted: Huemer (1891) 106-107; Huemer (1885) 94; Hecquet-Noti (2011) 168-170; Zwierlein (1994) 52-53. 
in the light of the communicative purpose and function of each poetic work. An idea of the different compositional orientations in relation to the overall structure of the works can be gleaned from the following tables:

Table 1: The Episode's Position within the Compositional Structure

\begin{tabular}{|c|c|c|}
\hline Authors & Preceding Section & Following Section \\
\hline Juvencus & $\begin{array}{l}\text { II. } 622-652: \text { entrance into Jerusalem } \sim \mathrm{Mt} \\
21.1-16 .\end{array}$ & $\begin{array}{l}\text { II. } 674-691 \text { : challenge of Jesus' au- } \\
\text { thority Mt } 21.23-27 \text {. }\end{array}$ \\
\hline Sedulius & $\begin{array}{l}\text { II. } 31-39 \text { : healing of two blind men } \sim \text { Mt } \\
\text { 20.29-34, Il. } 40-41: \text { healings in the temple } ~ \\
\text { Mt } 21.14-17 .\end{array}$ & $\begin{array}{l}\text { Il. } 57-63 \text { : healing of a mute man } \sim \text { Lc } \\
\text { 11.14-16; cf. Mt } 9.32-33 \text {. }\end{array}$ \\
\hline Avitus & $\begin{array}{l}\text { II. } 379-416 \text { : list of the biblical books suitable to } \\
\text { moral edification. }\end{array}$ & $\begin{array}{l}\text { II. } 441-502 \text { : parable of the ten virgins } \\
\text { and exegesis. }\end{array}$ \\
\hline Severus & $\begin{array}{l}\text { Il. } 40-92: \text { healing of a paralysed man at the } \\
\text { pool of Bethesda } \sim \text { loh } 5.2-18 .\end{array}$ & $\begin{array}{l}\text { II. } 143-162 \text { : Jesus' speech on the } \\
\text { power of faith } \sim \text { Mt } 21.21+\text { Lc } \\
17.7-10 \text {. }\end{array}$ \\
\hline
\end{tabular}

Table 2: Alternation of Narrative Sections and Exegetical Asides

\begin{tabular}{lrrrrr}
\hline Authors & Verses in Total & Narrative Section & $\%$ & Exegetical Aside & $\%$ \\
\hline Juvencus & 22 & 22 & 100 & 0 & 0 \\
\hline Sedulius & 15 & 10 & 66.66 & 5 & 33.33 \\
\hline Avitus & 24 & 8 & 33.33 & 16 & 66.66 \\
\hline Severus & 48 & 10 & 20.83 & 38 & 79.16 \\
\hline
\end{tabular}

\section{Spatio-Temporal Coordinates}

The retention of spatio-temporal coordinates reflects the need to guarantee that the episode is arranged as an organic narrative within the whole sequence of events ${ }^{9}$, in accordance with the classical rhetoric, which prescribes starting a narrative a per-

9 Sedulius (IV.42: talia ... post facta) and Severus (IX.93 post haec) link the narrative incipit with the previous section of the text through temporal conjunctions referring to past events, in order to obtain a coherent narrative sequence. At III.653 Juvencus prefers an opening formula that, though referring to the preceding narrative section, focuses on the words that Christ has just pronounced. It is a common device, through which the author generally links more diegetic sections, thus underlining the importance of the main character's words. In Sedul. carm. pasch. IV.43 the neuter uicina can be intended to mean either the "neighbourhood" of Bethany or the "neighbour" Bethany. 
sona or a re, and the principle of unity typical of epic poetry. Free from this compositional necessity, by contrast, is the choice of a single biblical unity expounded by Avitus, who introduces the episode by an unspecified quondam, an internal diegetic signal. Juvencus reprises the toponym Bethania (Bethaniam ... petit) and then accurately follows Matthew in referring to Jerusalem and its inhabitants (linquens cum ciuibus urbem $)^{10}$; he introduces, however, the epithet ingratam, which anticipates the possible identification of the city with the barren fig tree that has to be destroyed; this identification is suggested by the patristic sources and also on the basis of Ier 8.13. On an intertextual level, however, the possible reference to Vergil, ecl. 1.34 ingratae...urbi, which is nowhere else attested in Latin poetry, can be classified as a significant conceptual transposition: the ingratitude, which in the eclogue relates to the city dwellers, who, according to the interpretation of Servius, are guilty of scoffing the products of Tityrus and the farmers ${ }^{11}$, is transferred in the paraphrasis to Jerusalem, which refuses the salvific gifts offered by God through his Son.

On the other hand, completely free from negative implications is the epithet $D a$ vitica, which Sedulius ascribes to Jerusalem, on the basis of some Old Testament formulations ${ }^{12}$. Severus is the only one to mention the presence of the disciples, found in verse 11 of Mark's writing, which is a necessary elucidation in the narrative framework built by the poet, who, underlining the role of the disciples as the first recipients of the symbolic explanation of the prodigy, makes them a projection of the reader who is to be instructed. In the very first verse, the final clause iustissimus auctor, already found in Ov. met. XV.833 ${ }^{13}$ with reference to Augustus, represents a clear example of an ersetzende Übertragung ${ }^{14}$; in a contamination of cultural models, however, the Ovidian reminiscence blends with the traditional messianic attribute of Christ, defined as auctor already in Hbr 2.10 and 5.9. The reference to justice, another biblical divine prerogative, discloses the reason behind the supernatural deed, carried out, as the poet points out in I.136, "without injustice (sine crimine)"15.

10 This expression allows the author to condense the expression of Matthew relictis illis abiit foras extra ciuitatem. For the locution cum ciuibus urbem see Lucr. VI.590: cum ciuibus urbes and 1140: ciuibus urbem (= Verg. Aen. V.631; VIII.571; Lucan. I.592).

11 See the interpretation of Serv., ad buc. 1.34: INGRATAE VRBI quia cum alimenta ciuitatibus praestentur ex rusticorum labore, in his rustici et deridentur a ciuibus, et multa perdunt, et aduectarum rerum pretia iniqua suscipiunt.

12 Cf. II reg 5.7: arcem Sion, haec est ciuitas Dauid e III reg 2.10: in ciuitate Dauid.

13 Cf. also Ov. met. VIII.101 with reference to Minos.

14 Cf. Thraede (1960) 1034-1041; Stella (2006) 10-13.

15 Unlike Juvencus, the author of the In Euangelia amplifies with luci ... futura the temporal specification mane of Mt 21.18, varied by Sedulius (IV.44) with the poetic nexus clarescente die. The location of the tree is also significantly different in the four versions. Juvencus, consistent with the hypotext of Matthew, places it on the side of the street (1l. 654 s.: in margine ... / stratae); Sedulius, who in the prose redaction (IV.5) refers to the scriptures with haud procul a semita, in the hexametric version opts for a more poetic mediis ... in aruis (IV.45). The particulars of the location are, by contrast, completely omitted by Avitus, who with the participle uianti, echoing the coradical uia of the Gospel, alludes to the fact that the tree was placed alongside the street travelled by Christ; the same happens in 


\section{The Lord's Hunger}

In the biblical model, Jesus' search for fruits points to a physiological need of his, which is not further specified or motivated, so someone who interprets the text from a historical point of view run could into difficulties and some exegetes have been forced to give a non-literal interpretation ${ }^{16}$. Thus, it is striking that only in Severus, the only one among the four to provide a detailed theological comment on the biblical passage, is a reference to this motivation completely lacking, to the detriment also of the logical sequence of the narrated events. Behind this omission lies maybe the necessity to avoid a possible exegetical difficulty by exclusively selecting material on which a comprehensive interpretation of the scriptural text can be built, more than a form of negligence in reproducing the narrative moves of the source.

The refined periphrasis cibi pertemptans corda uoluntas of Iuvenc. III.656 offers, instead, a subtle form of interpretatio, which indirectly stresses the human nature of Christ. The abstract subject uoluntas ${ }^{17}$ seems to personify a negative and hostile force ${ }^{18}$, whose action is explained through a particularly expressive verb, in the intensive form ${ }^{19}$, which recalls the concept of temptation. While pertempto, attested only

the rendition of Severus who, noting the fact that the tree was isolated (IX.96: quae sola stabat), adds a detail that is not explicitly expressed in the model, unless one wants to understand in this sense unam of Mt 21.19, which, however, as is usual in biblical Latin, has the meaning of an article. Cf. Leumann-Hofmann-Szantyr (1972) 193.

16 On these historical and theological implications, see Bartsch (1962) 256-260.

17 While the reading uoluntas is attested in the vast majority of the manuscripts, the codices $\mathbf{T}(=\mathrm{Tu}$ ricensis C 68, saec. IX) and Bb (=Bobiensis [nunc Ambrosianus C 74], saec. IX-X) show the variant uoluptas, which would of course be much more typical and explicit with regard to the concept of desire, appetite expressed by the text. It must be stressed that in the Euangeliorum libri the term uoluptas is nowhere else attested, apart from I.418 as a minor variant and in III.333 as a conjecture of the 16th century editor Theodor Poelmann. On the other hand, there are in the whole text nine instances of uoluntas, all in the same metrical position. It cannot be excluded, however, that the authentic reading is, in fact, uoluptas and that this word, possibly perceived to be disrespectful if referring the Saviour, was later corrected by a medieval scribe into an semantically less expressive alternative.

18 According to a recurring use in Juvencus' paraphrase, which in this way tends to give substance to certain spiritual or psychological phenomena, such as the malice of the scribes and Pharisees, the Devil's tricks, etc. Thus, in this case, the use of the abstract noun fits into this series of examples and indirectly points to those negative forces that operate against Christ, hampering his actions. Hatfield (1890) 30, and Fichtner (1994) 158-167, have demonstrated how this preference for abstract nouns (which is a peculiar feature of Christian authors) must be ascribed to the canons of the poetry of late antiquity, especially of the Constantinian era.

19 While it is true that in the Euangeliorum libri these intensive and frequentative forms do not have meanings different from the corresponding simple ones, as is usual in late antique Latin, it is also true, however, that in some cases, since they are more substantial and forceful, they are more suitable to convey concepts that are particularly relevant or to underline incidents or actions that are crucial to the narrative structure. For a list of frequentatives in Juvencus, see Hatfield (1890) 34. 
here in the Euangeliorum libri ${ }^{20}$, possibly derives, in conjunction with corda, recta via from Stat. Theb. V.445f. tacitis corda aspera flammis / Lemniadum pertemptat Amor, the cognate words temptare and temptatio are largely used in the poem to indicate the action of the Devil and of the enemies of Christ. This is the case, for example, and this detail is not unimportant, of the narrative of the temptations in the desert in the first book, in which we observe the Devil proposing to the starving Lord the possibility to turn stones into bread ${ }^{21}$. This interpretation, only roughly sketched out there, finds its complete form in the later patristic commentaries, as e.g. Jerome's, in which, nonetheless, the allegorical and spiritual meaning of the hunger, which had already emerged at least as early as Origenes ${ }^{22}$, prevails.

\section{The Description of the Plant}

The biblical sources alternate the synonymic variants ficulnea and ficus (appearing alone or, in the genitive, dependent on the substantive arbor). According to his desire for uariatio, Juvencus uses a wider set of synonyms, starting from ficus (III.655) found in the model and meaningfully used only in the exordium of the narrative to define its thematic core, to arbor (III.660. 661. 668) and lignum (III.663). The choice of these two terms, and particularly of lignum, which indicates an already withered plant, seems to be anything but haphazard, if we take into account that, according to the subsequent patristic tradition, in the narrative of the Passion, the synecdoches "tree" and "wood" are equivalent to Cross. The term lignum, like its Greek equivalent

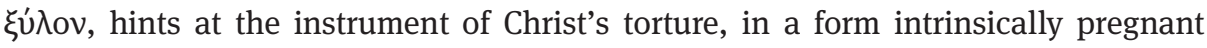
with Old and New Testament significances, e.g. the tree of the Genesis, the curse of Dt 21.23 and, indeed, the barren fig tree ${ }^{23}$. The detail of the shadow cast by the tree (1. 655 tendentem diffusa umbracula ficum) recalls, on an intertextual level, Tibullus' verbiage (II.5.97) about an old tree that shelters the farmers during the Palilia ${ }^{24}$; on an intratextual level, it recalls, with slight modifications, the expressions through which in II.115-17 cum te diffusae tegerent umbracula ficus, / ante etiam quam te uocitarent uerba Philippi, / uidit Juvencus amplified Ioh 1.48 priusquam te Philippus uo-

20 The passage of Juvencus is noted in ThlL X 1778, 48 under the rubric "c. notione afficiendi (in relation to animated beings)".

21 Cf. I.368; 374; 383; 396; see also I.599; II.476; 586; III.222; 464; IV.2.

22 Cf. Hier. in Matth. III.21.18: esuriit, uel ueritatem humanae carnis ostendens uel esuriens salutem credentium et aestuans ad incredulitatem Israhelis. This spiritual interpretation, on which also the parallel passage of Mc 11.13c (Luz [1997] 199-200 and n. 16) could have had an influence, is largely developed in Greek and Latin patristic literature; cf. Ioh. Crys. hom. 67.1 (= PG 58,634); Aug. serm. 98.3; also the anonymous author of the Opus Imperfectum in Matthaeum 844 focuses on the hunger not of food but of justice and salvation.

23 Cf. Roberts (1985) 200, and Piscitelli (2007) 129-152.

24 On the identification of the religious festival alluded in Tibullus' elegy and on the cited verse see the notes of Murgatroyd (2002) 224-225, and Maltby (2002) 459. 
caret cum esses sub ficu uidi te, where the fig tree, a symbol of Israel, points to the conversion of Nathanael.

Sedulius' description tends to focus the attention on the aesthetic of the tree, through a rich usage of adjectives and metrical-rhetorical devices. The first hemistich 46, emphasised by the alliteration frondea ficus, closes the metrical period started in the preceding verse by the formula ecce autem, which introduces the new, surprising event. The participle astans, framed between the penthemimeres and the hephthemimeres, and especially the adjective sublimis, picture the tree towering in the middle of the countryside. If astans in conjunction with syntagmata formed by in+abl. is common in epic poetry, the possible reminiscence of patristic commentaries ad loc. must not be underestimated. Jerome, e.g., in the traditional analogy between the fig tree and the synagogue, defines the plant as stantem scilicet et immobilem et non habentem euangelii pedes (in Matth. III.21.18). In this case, too, the epic dictio requires a lexical diversity that places robore, stipite and arboreis comis beside the biblical ficus and ficulnea. Of great interest is the restoration of this last term, which enters the poetic dictionary thanks to Sedulius ${ }^{25}$. It is a typically biblical word picked up then by the ecclesiastic writers, like Ambrose ${ }^{26}$ and Augustine ${ }^{27}$, mainly in negative contexts, often related to the Jews.

Avitus talks about delicate and extended fronds. The adjective diffusa (1. 418), although largely used in poetry with reference to the width of plants, might bring to mind at this precise point of the description, the text of Juvencus, recurring in the same metrical position. It also activates the intratextual identification with the luxuriant fig tree in Paradise, from whose cortex Adam cuts a strip to cover himself, which is described by the poet in III.12-15 (umbrosis propter stabat ficulnea ramis / frondentes diffusa comas, quas protenus Adam / umentem capiens raso de cortice librum / adsuit et uiridi solatur ueste ruborem). This is a simple mnemonic reuse, to be sure, but probably also a clue to a tacit parallelism between the two plants, suggested, as we will fully see in Severus, in patristic thought. The chiastic structure of 1.421 indutam tantum foliis, sed germine nudam, divided into two parts by the coincidence of the hephthemimeres and the syntactic pause, emphasises the opposition between the two antithetic characterisations, with homoeoteleuton, underlining the contrast between the luxuriant foliage and the absence of fruits. In the following depiction of the withering, Avitus stresses, with greater emphasis than his predecessors, the biblical reference to the presence of leaves only, also through a web of characterisations and a verbal accumulation aimed to reflect the meaning (1. 422 ... inane uirens ornatus inutilis ...). This may show the influence of the previous and contemporary patristic interpretation, which, in an overlapping of symbolic levels, built the allegorical comparison between Israel and the pharisaic traditions precisely on the

25 Apart from the passages of Avitus discussed below, the term is found in poetry also in Ven. Fort. carm. V.2.33; Columba hymn. I.256; Inscr. chr. Rossi II.247.10.1.

26 Iac. I.1.4: de infructuosa ficulnea dicere, hoc est malitia Iudaeorum.

27 Serm. ed. Mai 97.14: infructuosa synagogae ficulnea. Cf. ThlL VI 650, $19 \mathrm{ff}$. 
foliage. According to Hilary, the Synagogue is covered in leaves, i.e. empty words, but lacking fruits, i.e. good actions (in Matth. III.21.6 Inveniet infecundam, foliis tantummodo uestitam, id est, uerbis inanibus gloriantem, sed fructibus uacuam, operibus quippe bonis sterilem, et expectatis prouentibus nudam); similarly, Jerome insists on the empty orotundity of the Pharisees' speeches, which do not bear any truthful fruit (in Matth. III.21.19 nihil ... inuenit in ea nisi folia tantum, promissionum strepitum, traditiones Pharisaicas et iactationem legis et ornamenta uerborum absque ullis fructibus ueritatis). The terminological and conceptual coincidences might suggest a direct or indirect use of these commentaries by the poet.

Completely isolated remains the uncommon form caricem (maybe derived from a nominative carice or carix mentioned only in the Corpus glossariorum Latinorum ${ }^{28}$ used by Severus, who also uses the more common ficus at 1. 108. At VIII.157, in the episode of Zacchaeus, this word replaces the biblical sycomorus, which is found in the vast majority of the Vetus Latina manuscripts. In that case, unless a gloss read by Severus in some obscure source is conjecturable, the substitution might have been introduced for metrical reasons, with the aim of replacing the Greek calque of the model with a term more appropriate to the hexameter, the alternative and more common form of carice, namely carica, being already attested in poetic language since Ovid ${ }^{29}$. However, the problem of the choice of such a rare morphological variant remains. Apart from a possible mistake in the textual transmission, i.e. the change of caricam to caricem, which for paleographic reasons is not so unbelievable, we could take this form as a hint at the Greek cultural roots of the author, who elsewhere flaunts unusual lexemes, as is observed by Zwierlein in his prefatory words.

\section{The Curse}

The retention, in three cases out of four, of the direct speech, which draws attention to the passage in question, confirms the general tendency of the biblical epic poets to literally reproduce Christ's words or those about the relationship between Christ and God, especially in those episodes about miracles and healings ${ }^{30}$. At 1l. 659f., Juvencus specifies the recipient of the curse, but he substitutes illi of the VL with an archaic and more solemn olli, expressing the implied subject Christus with a common transitional formula in the Euangeliorum libri ${ }^{31}$. The lexical choice is effective, playing on the ambivalence of the word copia, employed here in the figurative sense of "potestas, facultas” (ThlL IV 909, $20 \mathrm{ff}$.) - which is actually attested in the poem only here

28 Gloss. III.538.49; 546.13 and Zwierlein ad loc. Noticeable is the correptio of the first syllable metri causa.

29 Cf. Ov. met. VIII.674: hic nux, hic mixta est rugosis carica palmis; fast. I.185: "Quid uult palma sibi rugosaque carica” dixi; Seren. med. 974: carica uel betis lento cum melle iugetur.

30 Cf. Roberts (1985) 138.

31 Cf. Rodríguez Hevia (1980) 255-271. 
-, yet at the same time allusively connected to the original meaning of "abundance" (in relation to the fruits), in which sense it normally occurs in the poem ${ }^{32}$. The restricted space of the second hemiepes 660 palpably works on the sense, conveying the idea of the immediateness of the drying.

In Sedulius, the recipient of the curse is the foliage, which is more than a simple synecdoche; we can observe here the author's intention to polemically emphasise how such a prosperous exterior, the implicit cause of the barrenness, will in future correspond a lack of fruits. The author is the only one to maintain the temporal annotation in sempiternum (1. 49 reliquum ... in aeuum) ${ }^{33}$, which Juvencus and Severus completely omit. Also remarkable in the Sedulian version is the insertion of ex germine vestro ("from your stock"). In the narrow sense, the expression denotes the tree's sprouts but, according to the recurring allegorical reading of the Fathers ${ }^{34}$, it also figuratively points to Israel's offspring. The abundance of descriptive details that portray the fig tree as drained of its lymph, dead and with dry branches, is an example of synonymic amplification, as noted by Roberts ${ }^{35}$; according to traditional rhetoric, this figure of speech conveys to the reader the importance of the passage, thus allowing the poet to display his stylistic abilities and refined lexical repertoire.

Frame by frame, like an Ovidian metamorphosis, Avitus describes each phase of the wilting, which gradually involves the entire plant, starting from the verdant crown, which by now has stiffened, to the roots, which have been overwhelmed by a sudden heat, to the trunk, which is dried and devoid of branches. The clause of 1. 423, adflata calore, is a borrowing from Sidon. carm. 11.126 proxima quin etiam festorum afflata calore, from the epithalamium for Ruricius and Iberia, where it indicates the heat that floods the nuptial room, whichever season it is. The Sidonian reminiscence then blends with another one, of Stat. Theb. X.674 fulminis haud citius radiis adflata cupressus, where the poet talks about a cypress hit by lightnings. A lexical similarity is found also between 1.424 ramorum tegmine and 1.26 of the pseudoCyprianic De Pascha, where the author refers to the shadow cast by the branches, in a depiction of Heaven according to the locus amoenus topos. Apart from a taste for descriptive preciosity, widespread at the time, the emphasis on the transformation exalts the grandiosity of the miracle, causing the barren beauty of the fig tree to appear more inconsistent and fragile.

Severus underlines the centrality of the curse by insisting on the notion of "word". While the "iunctura" siccauit verbo finds an immediate parallel in Eusebius

32 Cf. I.344: horreaque inplebit secreti copia farris; I.460: illos plena manet satiandos copia mensae; I.653 crastina nec uobis curetur copia rerum; II.753: incrementa sui centeno copia fetu.

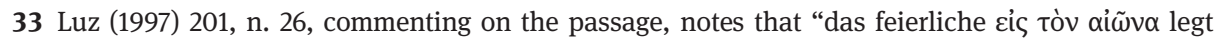
keine zeitliche Begrenzung nahe”.

34 Cf., e.g., Hilary's commentary on the passage in question (in Matth. 21,7 infidelitatis Iudaicae sterilitatem aeternae damnationis sententia consequetur).

35 Cf. Roberts (1985) 154-155. 
of Emesa ${ }^{36}$, a comparison must also be made with a passage of Commodian (instr. II.10.9-11):

... sterelis Christianos uos esse designo.

Maledicta fuit arbor sine fructu ficulna

in uerbo Domini et statim exaruit illa ${ }^{37}$.

The allusion to the parable of the barren fig tree, which complements the allusion to the parable of the chaff rewritten in the previous portion of text, clarifies in which precise sense the Pauline exhortation of Eph 6.8, evoked in 1. 5 Lex ager nobis est: qui fecerit bonum in illa, must be understood. With a metaphorical language of Cyprianic origin ${ }^{38}$, Commodian defines as "barren" those Christians who are incapable of performing charitable acts, thus proposing a spiritual explanation of the evangelical passage that is not so different from the one given by Sedulius and Avitus, despite the specificity of the relative contexts. But it is the reference ex novo to the power of the word that performs the miracle that brings into contact the text of Severus with the one of Commodius, and thus with the one of Eusebius. I find this parallel noteworthy, given that, in his recent commentary on the Instructiones, Poinsotte ${ }^{39}$ traces for the expression in uerbo Domini only a single possible formal model in Syracides 48.5. Apart from an indemonstrable interdependence between Commodian and Eusebius, whose speeches were translated into Latin between the end of the 4th and the beginning of the 5th century, or the influence of a common patristic source, the conceptual coincidence shows the strong influence wielded by the immediate effect of the curse on the Christian writers ${ }^{40}$.

\section{The Reaction of the Disciples}

Juvencus emphasises the disciples' astonishment not only over the miracle, but also over its immediate realisation, and stresses this feeling with a crescendo of psychological remarks, from mirantur to the figura etymologica stupidis ... /... stupuistis (1l. 662-663). In comparison with the Gospel, the insertion of the participle adsistens, which introduces the following answer of Christ, also appears significant; intention-

36 Cf. Euseb. Emes. serm. 11.2: interrogationem quamdam de illa fici arbore, quam dominus uerbo siccauit and the commentary of Zwierlein (1994) 110.

37 "I intend that you, Christians, are barren. The fig tree was cursed and thanks to the strength of the Lord's words immediately withered."

38 Cf. Cypr. eleem. 8; 9; 15; 22; 23.

39 Poinsotte (2009) $378-379$.

40 In the passage of Commodian the expression may refer either to the textual portion of 1.10 or to that of the following line. In any case, of crucial importance is the emphasis on the Lord's word, further emphasised by the metrical position of the syntagma in verbo Domini (with instrumental value) at the opening of the line. 
ally ambiguous, this verb alludes both to the fact that the protagonist is physically close to the disciples ${ }^{41}$ or witnesses their astonishment ${ }^{42}$, and to the fact that, with a shift in sense, he offers them assistance, instructing them by his explanatory answer $^{43}$. In a swerve from the hypotext, 'Severus' the fear more than the astonishment, transferring onto the disciples' emotions and their behaviour what elsewhere in the Gospels characterises the reaction of the crowds towards Christ's miracles (Mt 9.8 uidentes autem turbae timuerunt et glorificauerunt Deum and Lc 7.16 accepit autem omnes timor, et magnificabant Deum). This variation, which emphasises the importance of the event, acquires especially a theological and catechetical significance, thanks to the parenthesis on the omnipotence of God's word ${ }^{44}$. If, as the editors believe, the work was composed in the strong anti-Arian atmosphere that characterised the Visigothic Spain of the second half of the 6th century, the formulation carries a Christological substance, aimed to reaffirm, in an indirectly polemic way, the divine nature of Christ and his consubstantiality with the Father. The absence of this fundamental biblical aside in Sedulius and Avitus, apart from their respective poetic intentions, aims to uncouple the event from the temporal coordinates of the incident of the Gospel, with a view towards actualisation. In other words, the disciples are replaced by the recipients of the work, who are offered the subsequent interpretation with a parenetic purpose.

\section{The Vocabulary of the Miracle}

The vocabulary used to denote the miracle is indicative of the poetic purposes and the times of composition. Thus, it is not surprising to find, in the Euangeliorum libri, a term like honor (III.663 nunc ligni istius nostro stupuistis honore), which is not characterised as Christian, but culturally compatible with the feelings of the

41 Canali (2011) 183; McGill (2016) 90.

42 Galli (2012) 211.

43 On this meaning of adsisto cf. the entry by Münscher in ThlL II 901, 82ff.

44 I think that the conjecture uerbum proposed by the editor Thomas Klein (as is inferable from the critical apparatus) to fill the gap of 1.102 must be preferred to the addition regem suggested by Willy Schetter. In this specific context, in fact, the reference to the word, which must be understood metonymically here, as relating to God or to his Son, according to the New Testament definition of Ioh 1.1-3 (in principio erat Verbum, et Verbum erat apud Deum, et Deus erat Verbum. Hoc erat in principio apud Deum. Omnia per ipsum facta sunt), acquires a particular relevance and helps to emphasise the greatness of the miracle just realised only through the word pronounced by Christ, the incarnate verb. The conjecture, which would acquire greater effectiveness also on a stylistic level thanks to the polyptoton with uerbo of 11.98 and 100, seems to be supported also by a series of intratextual parallel passages noted by Zwierlein (1994) 111. Furthermore, in the text of Severus, on the basis of the aforementioned passage of John, the clause cuncta peregit has a gnomic value, through which the author intends to underline God's power over nature, an aside, which in this case, with a reference to the specific prodigy narrated, aims to recall the fact that He, who has created everything, has also got the power to regulate and dominate the natural cycle of things. 
Roman audience. The same term recurs in IV.400 pars credens sequitur tantae uirtutis honorem, but in a syntagma with uirtus, periphrastically formulating a miracle that has already happened, namely the resurrection of Lazarus. This word, which covers a wide semantic range, denotes in the Latin world, in sacral contexts, the religious devotion or the concrete demonstration of pietas towards the gods (sacrifices, libations, votive offers; cf. ThlL VI 2921, $74 \mathrm{ff} . ;$ 2924, $61 \mathrm{ff}$.). For the benefit of the audience, the miracle is represented, according to epic modes of expression, as an act of submission and deference of the natural elements, in this case the plant (ligni is here a subjective genitive) towards the superior will of the God-man. In the later compositions of Avitus (VI.425 instruimur tali legem cognoscere signo) and Severus (IX.104 quod signo fecit), the technical term signum easily finds its place, a typical lexeme of the Christian Sondersprache, where it occurs in its double meaning of "signe, préfigu-

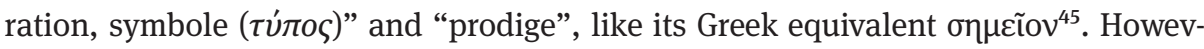
er, especially noteworthy, as a witness to the changes in times and circumstances, is the fact that in both cases, in spite of, as we will see, the difference of the contexts and of the subsequent exegetical implications, the substantive precedes a more or less ample section of commentary. The signum, in fact, being anticipation or a symbol of something else, must be explained, contextualised and interpreted.

\section{Exegesis}

The lack of an exegesis is compensated in Juvencus by a thick web of intertextual references. In the final passage about rocks and animals, in which Green sees a touch of humour ${ }^{46}$, an allusiveness can be observed that acquires its own value as an exegetical amplification. At III.671, in the sequence siluis ... saxisque ferisque, the commentators ${ }^{47}$ point out echoes of Ov. met. XI.1-2 carmine dum tali siluas animosque ferarum / Threicius uates et saxa sequentia ducit (of Orpheus) and XIV.338-40 siluas et saxa mouere / et mulcere feras et flumina longa morari / ore suo uolucresque uagas retinere solebat (of Canens). The Ovidian reminiscences, especially the one of the Thracian cantor, obtain an allusive power that has not yet been adequately stressed by critics. The poet seems to suggest, in fact, an implicit analogy between Orpheus and Christ. This analogy characterised early Christian iconography and was decoded on a typological level in the patristic witnesses, starting at least from Clemens of Alexandria, who emphasises how the real Orpheus is the Logos, able to wield his power not only over animals but over natural elements and men's hearts, too ${ }^{48}$.

45 Blaise-Chirat (1954) 759.

46 Green (2006) 86.

47 Cf. Zuliani (2005) 329; Santorelli (2011) 375-376; McGill (2016) 229.

48 Clem. Alex. protr. 1.2-5. The Christianisation of the Orpheus myth, starting especially from the analysis of passages from Clemens of Alexandria and Eusebius of Caesarea, has recently been dis- 
The text of Sedulius is established on a different level that develops a minimal interpretation of the parable in the form of a moral exegesis. With the allegorical deepening of the literal foundation, focusing on a triple botanical similitude distinguished by the usage of comparative tags (ceu, aequabitur, similis, tamquam), the poet gives to the narrative detail a theological depth, or at least a spiritual one, open, even on a poetic level, to different reading possibilities. In this case, the allegory makes use of intra-biblical references both in the comparison between the barren faith and a dry trunk, comparable with passages of Mattew ${ }^{49}$ and Luke $^{50}$, and in the comparison between the upright people and the Cedar of Lebanon, found in psalm.91(92).13, which is quoted literally in the prose version (iustus ut palma florebit et sicut cedrus, quae in Libano est, multiplicabitur). The ideological fundament of this exegetical insertion must be sought in the Opus Paschale, where, with a programmatic declaration, the interpretation of the narrative is shifted from the literal sense (ad litteram) to the allegoric-spiritual one (spiritales causae), more appropriate to the lex diuin $a^{51}$. The greater thoroughness of the prose rewriting allows greater clarity, necessary in the field of faith, which is diluted by poetic polysemy. This is further confirmation that the Opus, more complete and exhaustive on the level of content, is conceived by the author as an instrument for a better understanding of the poetic composition, which was published before ${ }^{52}$.

In Avitus a notable double exegetical level goes from the general to the particular. First, the biblical exemplum is, in fact, explained on an ethical-moral level, suitable for the parenetic-pastoral purposes of the poem. In the light of this first level, it is possible to catch the sense of the subsequent link with chastity, expressed as a similitude, otherwise not so perspicuous (11. 430-40):

cussed by Arcari (2016), 41-88. On the Orpheus myth as a Christological image in medieval Latin literature see Dronke (1998), 55-79.

49 Cf. Mt 3.10: iam enim securis ad radicem arborum posita est; omnis ergo arbor quae non facit fructum bonum exciditur et in ignem mittitur and 7,19: omnis arbor quae non facit fructum bonum exciditur et in ignem mittitur.

50 Cf. Lc 13.6 - 9: dicebat autem hanc similitudinem: arborem fici habebat quidam plantatam in uinea sua et uenit quaerens fructum in illa et non inuenit. Dixit autem ad cultorem uineae: ecce anni tres sunt ex quo uenio quaerens fructum in ficulnea hac et non inuenio; succide ergo illam ut quid etiam terram occupat. At ille respondens dixit illi: domine dimitte illam et hoc anno usque dum fodiam circa illam et mittam stercora et si quidem fecerit fructum, sin autem in futurum succides eam.

51 Cf. op. pasch. IV.5: Non tamen haec accipiamus ad litteram, licet manifesto credantur impleta, quoniam spiritalibus causis conuenit lex diuina. Quid enim materies sine sensu peccauerat? Praesertim quae fructum, sicut Marcus euangelista commemorat, incongrui ratione temporis non habebat: nisi ad instructionem Dominus nostrae utilitatis hoc ageret, qui factorum sermonumque parabolis uitale nobis iter ostendit.

52 The linguistic and rhetoric analogies and differences, as well as the ones related to content, between the poetic rendition and the prose have recently been discussed by Mori (2013), who underlines how the prose version aims to clarify the author's literary purposes. 
Sic et uirginitas sacro deuota pudori

indiget adiunctis uirtutibus et, nisi mentem

intactam seruans casto cum corpore iungat,

concumbit uitiis nec castam dicere carnem

iure potest, animus quam sic corrumpit adulter.

Ira, furor, maeror, liuor, discordia, luxus

lingua duplex, constricta manus, laxata uoluntas

moechantur cum corde hominis, tum semine turpi

fetus mortis alunt. En quo perducitur omnis,

nomine uirgineo quae se dum iactitat, intus

criminibus grauidam nescit turgescere mentem ${ }^{53}$.

What has generally been said about those who proclaim themselves Christians (1.426 Christi famulum solo sermone fatenti), namely that they must match this self-proclamation with a uiuens operatio (1.427), and that they must testify to their faith through acts of charity, is now applied specifically to the behaviour of the virgins. The under-

53 This is not the place to discuss this passage at length; it seems nonetheless necessary to highlight a few devices used by the poet to express effectively the moral teaching. In the first section, the accumulation of strongly positive adjectives, denoting the concepts of pureness and modesty, together with their respective substantives (1. 430 sacro ... pudori; $11.431 \mathrm{ff}$. mentem / intactam; 1.432 casto ... corpore; 1.433 castam ... carnem), anticipates the following contrast with the vocabulary of both the second and the last section, which focuses on the concepts of immodesty and adultery (1. 433 concumbit uitiis; 1.434 animus ... corrumpit adulter; 1.437 moechantur ... semine turpi). The vocabulary, which also through different communicative levels and different linguistic and stylistic registers conveys the antithesis between the two opposite realities that are represented, consists of verbs as concumbere, absent from Vergil and Horace, but frequent in the elegiac poets (ThIL IV 102, 18ff.), and moechari, which is chiefly used by Catullus and Martial, but also found in the Latin Bible, both in its literal and its metaphorical sense. These verbs belonging to the sexual sphere play a functional role in the formulation of a critic of the lack of spiritual purity. This highly allusive sexual lexicon culminates in the peculiar metaphor of the impure soul's pregnancy (1. 440 grauidam ... turgescere mentem), which, having fornicated with vices and sins, gives birth to deadly fetuses (1. 438 fetus mortis), that is to say bad actions. The sins that commit adultery with the hearts of human beings are listed in a long congeries at 1l. 435f., according to the traditional form of the Lasterkatalog, which is already used by the poet in carm. II.31f. (cessabit gemitus, luxus, metus, ira, uoluptas, / fraus, dolor atque dolus, maeror, discordia, liuor) with regard to the eschatological vision of the freedom from sins, and which finds immediate parallels in Prud. ham. 395-397: ira superstitio maeror discordia luctus / sanguinis atra sitis, uini sitis et sitis auri / liuor adulterium dolus obtrectatio furtum (about the Devil's army) and psych. 629f. Metus et Labor et Vis / et Scelus et placitae fidei Fraus (Operatio has just gained victory over Cupiditas); on this imitation of Prudentius, see Arweiler (1998), 48. What is missing in the previous catalogues is a reference to furor (to be understood here in the double meaning of "anger" and "uncontrolled lust", "passion", which the virgin may nourish in her soul) and the three pairs of noun+adjective, which at 1.435 follow the nominative-only list of 1.434 . On a stylistic level, the chiastic disposition of the nouns and the relating adjectives at $11.431 \mathrm{f}$. (mentem ... intactam ... casto ... corpore) and the alliterative sequence of $c$ at $11.432-434$ are noticeable. The contrast between a positive exterior and an interior dirtied by sins must recall Christ's condemnation of the formalism of the Pharisees, which is compared to whitewashed tombs, which, behind a pleasant appearance, hide the decomposition of corpses. 
lying reference to 1 Cor 7.34 (et mulier innupta et uirgo cogitat quae Domini sunt ut sit sancta et corpore et spiritu) summarises the ideal according to which true virginity combines pureness of the body with that of a soul that is kept free from sins and impure thoughts. On a literary level, the equation (leafy but barren fig tree $=$ Christians solo sermone = virgins chaste in their body but impure in their spirit) responds to the lack of epic similitudes within Avitus' work, supplying biblical-moral terms for comparison. Thus, the poet imparts to his main readers, namely his sister Fuscina and those Christians who adopted an ascetic life following the Lerinian example, those biblical passages that are connected to chastity or, as in this case, to be read with regard to chastity, applying a kind of moral exegesis for his parenetical purposes.

In comparison with a mere ten verses used for the poetic retractatio of the Gospel passage, we can count in the In Euangelia of Severus 38 verses of exegetical aside (1l. 103-140). The centrality of the exegetical component is especially demonstrated by the plurality of interpretational suggestions made by the author. Like Avitus, who, however, does not follow up with the theological implications, Severus, following the hypotext of Mark, notes the fact that Christ's search for fruits happens tempore non apto (1. 105), a parenthetical remark, which imposes on the reader the need to investigate further and go beyond the simple thaumaturgical deed. The Lord's gesture, otherwise incomprehensible, displays the divine soteriological perspective (1. 107 quo cunctos doceat clementia numina sancta). The poet proposes at this point three different interpretational readings of the evangelical passage:

a. 11. 108-118. The fig tree recalls the tree of life, under which the original parents found shelter after eating the forbidden fruit, and with the leaves of which they covered their nudity. In the context of this figural reading, the drying of the tree represents the deliverance brought by Christ, who burdens himself with men's sins, thus regenerating their hearts. This interpretation, widespread in the exegesis of the Fathers, is found, among others, also in Augustine; in serm. 122, commenting on the episode of Nathanael, the bishop of Hippo makes a comparison between the fig tree and the sin committed by Adam and Eve, identifying the tree as symbol of the $\sin ^{54}$.

b. To the first one, Severus adds a second exegetical suggestion introduced in 1.119 by ast alii credunt. According to others, in fact, in an eschatological sense, the

54 Cf. Aug. serm. 122.1: quod dictum audiuimus a Domino Iesu Christo Nathanaeli, si bene intellegamus, non ad ipsum pertinet solum. Ipse quippe Dominus Iesus sub ficu uidit omne genus humanum. Isto enim loco intellegitur per arborem fici significasse peccatum. Non ubique hoc significat, sed hoc loco, ut dixi, ea scilicet significandi congruentia, qua nostis primum hominem, quando peccauit, foliis ficulneis fuisse subtectum. His foliis enim pudenda texerunt, quando de peccato suo erubuerunt; et quae Deus illis membra, ipsi sibi pudenda fecerunt [...] Hoc autem dixi, quare? Ut per ficum intellegamus significatum esse peccatum. Quid est ergo: Cum esses sub ficu, uidi te? Cum esses sub peccato, uidi te. Et ad rem gestam quidem respiciens, recordatus est Nathanael se fuisse sub ficu, ubi non erat Christus. Also in Kontakion 54.3 of Roman the Melodist the tree of the terrestrial paradise, origin of Adam's sin, becomes the barren fig tree of the Gospel; cf. Catafygiotu Topping (1978) 22-35. 
unexpected gesture of Christ would serve as a warning of future punishment that is in store for evil people at the end of times. This argument reflects the one proposed by Isidore of Pelusium in epistle 1,51 addressed to the tribune Theopompus (PG 78,213): The anti-Arian polemist, who participated in the council of Chalcedon, but was barely known in the West (except for Facundus of Hermiane and Rusticus Deacon), had probably been read by Severus in a Latin translation of Greek chains.

c. 11. 124-136. With an implicit allusion to Judas' treason, a warning to the apostle takes place, in order to deflect him from his intentions and to redeem him. This unusual link might imply an underlying reference to the words of Juvencus, according to which Judas hangs himself from a fig tree $\mathrm{e}^{55}$. Whether this is an invention by Juvencus ${ }^{56}$ or a popular legend is hard to say; the legend may actually have arisen from the curse of the fig tree, although already in antiquity this

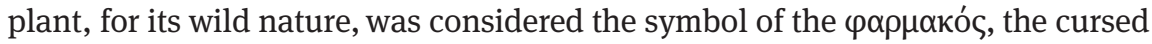
man who lives on the margins of society ${ }^{57}$. However, the possibility must not be ruled out that Severus derived the detail of the fig tree linked with suicide from Juvencus, in order to then create a link with the narrative of the cursed fig tree. The poet, anyway, clarifies in the statement of 1.137 diximus haec nostros sensus proferre uolentes that this is a completely personal interpretation, not derived directly from any other source. In support of his own interpretation, the poet then builds a complex similitude (11.128-136) in which he compares Christ to a doctor who, in order to save the life of his dying patients, sacrifices some animals to extract from them the necessary medicine. The worthy purpose, then, justifies the otherwise unintelligible action, which happens sine crimine (1.136). The refined similitude, which makes use of Greek medical sources ${ }^{58}$, which the author may have read in Latin translation, also retrieves the traditional theme of the Christus medicus, widespread in Christian literature, especially Augustine, in connection with its soteriological and Christological doctrine ${ }^{59}$. Nevertheless, on a literary level, the similitude, through which the poet enlarges and gives substance to his explanation, also matches the compositional characteristics of the epic genre.

55 Iuvenc. IV.630 - 631 exorsusque suas laqueo sibi sumere poenas / informem rapuit ficus de uertice mortem. See also Itin. Anton. Plac. rec. A 17: ibi est ficulnea in qua Iudas se suspendit cuius talea stat munita petris; on this anonymous Itinerarium Antonini Placentini, composed approximately between 560 and 570, cf. Milani (2002) $40-46$.

56 The author is however the most ancient source of this version of the death of Judas.

57 See Colombi (1997) 32, who conjectures that Juvencus followos popular legend in identifying the fig tree as the site of the suicide of Judas; Leone (2004) 92 refers vaguely to some apocryphal legends in which Judas hanged himself from a fig tree; McGill (2016) 264 quotes the Brescia Casket (ca. 394), wich features a figure, probably Judas, hanging from an oak tree.

58 See Zwierlein (1994) 116-117.

59 Cf. Hübner (1985) 324-335; Gollwitzer-Voll (2007); Weber (2013) 125-142. 
In any case, the exegetical effort of the author does not exhaust the multiple interpretative possibilities offered by the biblical text. And other interpretations will be given by other authors (11. 138-139 ast alios, quo quisque modo perquirere temptat, / inueniet). With the concluding picture, which compares the actions of Christ to precious gems, Severus not only recalls a biblical-patristic metaphor related to the Holy Scripture but also alludes to that preciosity typical of late antique artistic and literary aesthetic.

The usage of technical terminology related to the interpretational activity ("teach", "research" or "study") and the reutilisation of Lucretian expressions at 11. $137-140^{60}$ confirm the didactic character of Severus' poem. The didactic function, associated in the Gospels with Christ, is in the metaliterary play associated with the poet, who gives his readers a doctrinal and religious lesson. As Michele Cutino has poignantly pointed out in his recent work ${ }^{61}$, the final link between the gesta superna (1. 139), which are an echo of the Christi vitalia gesta (1. 19) found in the preface of Juvencus' Euangeliorum libri, and the need to interpret the actions of Christ in order to extrapolate a teaching from them symbolically marks the transition of the biblical paraphrasis from an epic-narrative modality to a fusion of epic and exegesis. With regard to Severus' readers, what is conceivable is not exclusively a scholastic purpose, a context of monastic-presbyterial education, but also a larger audience, constituted by culturally elevated classes that are pressed by the doctrinal questions that emerged from the growth in theological thinking, which took place in the Latin west at that time.

\section{Conclusions}

The poetic versions of the pericope, which reflect different literary sensitivities due to the changes in the socio-cultural contexts and the constantly new requirements of the readers, exemplify the evolution in the relationship between poetic expression and theological research and their reciprocal influence on each other. The initial phase of acquisition of the epic mode of expression having been overcome, which, due to the propagandistic need to spread the biblical text in palatable linguistic forms, imposed on Juvencus a more literal paraphrasis, the poetic approach to the scriptures that starts with Sedulius offers a new form, characterised by metaliterary interventions aimed at an intra-scriptural, allegorical or spiritual exegesis ${ }^{62}$. The biblical text, then, assumes a new context and a new function also in works that belong to literary genres different from the Bibelepos, as in the case of the De Virginitate of Avitus, or undergoes a strict exegetical analysis with additions that are no longer

60 E.g., l. 137 nostros sensus: cf. Lucr. IV.111-112: quoniam primordia tantum/ sunt infra nostros sensus; 1. 140 quocumque modo: cf. Lucr. II.774: nam quocumque modo perturbes caerula, quae sint. 61 Cutino (2016-2017) 201.

62 Cf. Stella (2001) 47. 
only narrative, but tend to convey theological messages and to explain specific doctrinal aspects.

\title{
Appendix: Texts and Translations
}

\author{
Mt 21.17-22 (VL: ed. A. Jülicher, Berlin 1938, 150-151)
}

${ }^{17}$ Et relictis illis abiit foras extra ciuitatem in Bethaniam ibique mansit. ${ }^{18}$ Mane autem transiens in ciuitatem esuriit. ${ }^{19}$ Et uidens fici arborem unam secus uiam uenit ad eam, et nihil inuenit in ea nisi folia tantum, et ait illi: "Numquam ex te fructus nascatur in sempiternum". Et arefacta est continuo ficulnea. ${ }^{20}$ Et uidentes discipuli mirati sunt dicentes: "Quomodo continuo aruit?"

${ }^{21}$ Respondens autem lesus ait: "Amen dico vobis: si habueritis fidem et non haesitaueritis, non solum de ficulnea facietis, sed et si monti huic dixeritis: tollere et mittere in mare, fiet. ${ }^{22} \mathrm{Et}$ omnia quaecumque petieritis in oratione credentes accipietis.
${ }^{17}$ And he left them and went out of the city to Bethany and stayed there. ${ }^{18}$ Early in the morning, as Jesus was returning to the city, he was hungry. ${ }^{19}$ Seeing a fig tree by the road, he went up to it but found nothing on it except leaves. Then he said to it, "Let there be no fruit from you henceforward forever!" Immediately the tree withered. ${ }^{20}$ When the disciples saw this, they marveled and said: "How did [the fig tree] wither so quickly?" 21 Jesus replied and said: "Truly I tell you, if you have faith and do not doubt, not only can you do what was done to the fig tree, but also you can say to this mountain: 'Go, throw yourself into the sea,' and it will be done. ${ }^{22}$ And whatever you ask in prayer, you will receive, if you have faith.

Mc 11.12-24 (VL: ed. A. Jülicher, Berlin 1940, 103-106)

${ }^{12}$ Et alia die cum exisset a Bethania, esuriit. ${ }^{13}$ Cumque uidisset a longe ficum habentem folia, uenit uidere, si quid esset in eam; et nihil inuenit nisi folia tantum: non erat enim tempus ficuum. ${ }^{14}$ Qui dixit ei: "Iam non amplius in aeternum quisquam fructum ex te manducet”. Et audiebant discipuli eius [...]. ${ }^{20}$ Et cum transirent mane, uiderunt arborem ficus aridam factam a radicibus. ${ }^{21}$ Et recordatus Petrus ait: "Rabbi, ecce ficus, cui maledixisti, aruit”. ${ }^{22}$ Et respondens lesus ait illis: "Si habueritis fidem Dei, ${ }^{23}$ amen dico uobis, quia quicumque dixerit huic monti: tollere et mittere in mare, et non haesitauerit in corde suo, sed crediderit futurum, fiet, quodcumque dixerit. ${ }^{24}$ Propterea dico uobis: Omnia quaecumque orantes petitis, credite quia accipietis, et euenient uobis".
${ }^{12}$ And on the morrow, when he came out from Bethany, he hungered. ${ }^{13}$ And seeing a fig tree afar off having leaves, he went to see if anything was thereon; and he found nothing but leaves; for it was not the season of figs. ${ }^{14}$ And he said to it: "No man eat fruit from you henceforward forever". And his disciples heard it [...]. ${ }^{20}$ And as they passed by in the morning, they saw the fig tree withered away from the roots. ${ }^{21}$ And Peter remembered and said to him: "Rabbi, behold, the fig tree which you cursed is withered away. ${ }^{22}$ And Jesus answering said to them: "Have faith in God. ${ }^{23}$ Verily I say to you, whoever shall say to this mountain: "Be taken up and cast into the sea", and shall not doubt in his heart, but shall believe that what he said will come to pass, it will be done for him. ${ }^{24}$ Therefore I tell you: All things whatever you pray and ask for, believ2e that you will receive them, and they will be yours. 
Juvencus, Euangeliorum libri III.653-674 (ed. I. Huemer, CSEL 24, Vindobonae 1891, 106-107)

Haec ait ingratam linquens cum ciuibus urbem Bethaniamque petit, rediensque in margine cernit stratae tendentem diffusa umbracula ficum. Illic forte cibi pertemptans corda uoluntas arboris adtrectat ramos, sed nulla facultas pomorum sterili frondis concreuerat umbrae. Olli Christus ait: "Non sit tibi fructibus umquam copia promendis." Tum protinus aruit arbor. Discipuli celerem mirantur in arbore mortem. Sed Christus stupidis adsistens talia fatur: "nunc ligni istius nostro stupuistis honore, desisse ad uires terrenos ducere sucos.

Sed ueris uerbis iterumque iterumque monebo: 665 namque fides si certa animi consistet in arce nec dubiis nutans uitiis tremebunda iacebit, arboris istius uobis substantia cedet. Nec tantum istius, sed montis celsa reuelli credentum uerbo poterunt undisque profundi cum siluis pariter saxisque ferisque recondi. Et quaecumque fides robusto pectore poscet, credentum semper digna uirtute tenebit." Haec ubi dicta dedit, templi se moenibus infert.
This said, he leaves the ingrate town and its inhabitants and goes to Bethany; returning, he glimpses on the roadside a fig tree, stretching

655 a wide sheltering shadow. There, by chance, the wish for food, seizing his heart, urges him to scour the tree's branches. But in the barren shadow of the leaves not a single fruit had grown. To the tree Christ says:"May you never have the power to produce", and the tree im-

660 mediately withered. The disciples wonder at the sudden death of the tree. Christ, coming near the astounded men, says: "Now you are astonished how this tree honored me, because it has ceased to draw sap from the soil for its nourishment. But again and again with truthful words I will exhort you: If your faith remains firm in the fortress of your soul and, trembling, does not fall, wavering in doubt and error, the essence of this tree will yield to you. And not

670 just this; if believers give the word, the mountain peaks can be torn up and cast into the depth of the sea along with woods, rocks and beasts. And what steadfast faith demands, it will always obtain due to the worthy virtue of believers". After these words, he enters the temple.

\section{Sedulius, Carmen Paschale IV.42-56 (ed. I. Huemer, CSEL 10, Vindobonae 1885, 94)}

Talia Dauiticam post facta reliquerat urbem Bethaniae uicina petens, eademque reuersus clarescente die properabat uisere tecta. Ecce autem mediis astans sublimis in aruis frondea ficus erat, cuius in robore nullum repperit esuriens lustrato stipite pomum; arboreisque comis "iam nunc ex germine uestro

nullus" ait "fructus reliquum generetur in aeuum".

Confestim uiduata suis ficulnea sucis aruit et siccis permansit mortua ramis. Omnis enim quicumque Deo nil fertile nutrit, ceu sterilis truncus lignis aequabitur ustis. At iustus palmae similis florebit amoenae, semper habens frondes et tamquam Libana cedrus multiplicandus adest et uertice sidera tanget.
After such deeds, he left the city of David and headed for neighbouring Bethany. At daybreak, heading back to Jerusalem, he was hastening to look at the buildings. But, behold, towering in the middle of a field stood a leafy fig tree: hungry, he searched the branches of the tree, but he did not find any fruit. To the tree's foliage he said: "Now, may never grow a fruit from your stock for all time". Devoid of its sap, the fig tree suddenly withered and remained

50 there, dead, with dried branches. For everyone who produces nothing fruitful for God, in fact, like a barren trunk, will be compared to wood that is burnt. But the righteous man will flourish like a luxuriant palm tree always in leaf 55 and will grow tall like a cedar of Lebanon and touch the stars with his crown. 
Alcimus Avitus, De uirginitate 417-440 (ed. N. Hecquet-Noti, Paris 2011, 168-170)

Esuriit quondam dominus, cum forte uianti conspicitur diffusa leui ficulnea fronde, nec iam maturum praedicta ex arbore fructum carpere tempus erat. Quam mox ut repperit ille 420 indutam tantum foliis, sed germine nudam, prorsus inane uirens ornatus inutilis horret, percutitur subito radix adflata calore aruit et posito ramorum tegmine truncus. Instruimur tali legem cognoscere signo: ne Christi famulum solo sermone fatenti nomine conficto uiuens operatio desit. Nam si Christicolas nosmet sanctosque putemus, adgrauat hoc etiam, ni dictum facta sequantur. Sic et uirginitas sacro deuota pudori indiget adiunctis uirtutibus et, nisi mentem intactam seruans casto cum corpore iungat, concumbit uitiis nec castam dicere carnem iure potest, animus quam sic corrumpit adulter.

Ira, furor, maeror, liuor, discordia, luxus, lingua duplex, constricta manus, laxata uoluntas moechantur cum corde hominis, tum semine turpi fetus mortis alunt. En quo perducitur omnis, nomine uirgineo quae se dum iactitat, intus criminibus grauidam nescit turgescere mentem.
One day the Lord was hungry, when, by chance, he glimpsed on his way a wide fig tree with delicate foliage, but it was not yet the time to gather ripe fruits of the tree. As soon as he noticed that the tree was covered only in leaves but devoid of seeds, the worthless ornament, uselessly flourishing, stiffens, the roots are flooded and hit by a sudden warmth,

425 the trunk, having lost the protection of the branches, dries out. From such a sign we learn the rule: The man who proclaims himself Christ's disciple only in words, after having given himself such a name, must carry out good deeds in his life. For if we consider our-

430 selves Christians and pious, it is even more unjustifiable if our deeds do not follow our words. Thus, chastity, too, devoted to holy demureness, needs other virtues to be added and, if it does not preserve a pure spirit to join it to a chaste body, it lies with the vices and

435 cannot rightfully call chaste the flesh thus corrupted by an adulterous soul. Wrath, insanity, affliction, envy, discord, lust, a duplicitous tongue, a chained hand, an uncontrolled will fornicate with men's hearts and then, with their shameful seed, feed deadly fetuses. Behold, where every woman is conducted who,

440 while boasting about her virginity, does not know that inside herself a sinful spirit is growing.

\section{Severus of Malaga (?), In Euangelia IX.93-140 (ed. B. Bischoff - W. Schetter - O. Zwierlein, München 1994, 52-53)}

Bethaniam post haec uenit iustissimus auctor discipulisque simul mansit; lucique futura pergens sic urbem coepit perquirere cibum, 95 et petiit caricem, quae sola stabat, et hic tum, cum non inuenit fructum (nec tempus erat nam), siccauit uerbo florentes arbore ramos "ex te" sic dicens "foetus non creuerit umquam!"

Quae uerbo citius demum siccata remansit. Quod cum uiderunt, pauidi coepere ministri laudare aeternum <uerbum>, quod cuncta peregit.
The righteous creator then arrived in Bethany and stayed there with the disciples; the following day, heading to the city, he began to look for food. He moved close to an isolated fig tree, and, not finding any fruit there (it was not the right time!), with his word made the branches, which flourished on the tree, wither, saying these words: "You will not grow any fruit ever again!" The tree withered even faster

100 than the words. Seeing this deed, the disciples, frightened, began to praise the eternal word, which accomplishes everything. This action, too, carried out through a miracle by the one who knows all past events, offers ex- 
Hoc quoque tractanti praebet documenta decora,

quod signo fecit, qui sciuit cuncta priora. Tempore non apto fructum perquirere coepit ostendens maius sese perficere uelle, quo cunctos doceat clementia numina sancta. Nam ficus fuit ista, prius quae stabat in horto regis iussa gerens, ne sumat primus; et illum forma repens quoniam legi succumbere fecit et foliis caelare sua iam turpia membra, haec post porrexit supero querente peremptum, nunc ideo damnata suum dimisit honorem. Quae male praestiterat fructum foliaque priora a Christo siccata docet, quod cuncta reformat 115 primitias scelerum sumens (quae fecit iniquus sic suadens homini legem calcare supernam) euoluens sceleri mortalia corda subacta. Ast alii credunt Christum siccasse, suapte ut doceat se posse feros damnare, quod illi credebant Christum solum perficere, nolle et punire malos: "hominem non perdit, eo quod

ipse deus dixit semet concedere cuncta." Atque ideo fecit: uoluit cohibere rapacem, ne se perdat amens prodens per lucra magistrum

cognoscens ipsum posse et damnare nefandos ex ipsis rebus seseque recolligat ardens.

Vt medicus, hominum custos, sanare uolutans occulta quos pestis agit, pernosse praetemptat membrorum positus, solitamque adhibere me- 130 delam

vestigat pecudum quidquid sic possidet artus ceu mortale genus, et uiscera uiua recludens porcorum morte uitam languentibus affert: debile sic Christus proprii cum cepit inopsque discipuli, uoluit damnata sub arbore firmum efficere ramosque ideo sine crimine siccat. Diximus haec nostros sensus proferre uolentes; ast alios, quo quisque modo perquirere temptat, inueniet, gemmae quoniam sunt gesta superna, quae, quocumque modo tractantur, pulchra uidentur. cellent teachings to those who investigate. He started to look for fruits at an unseasonable time, showing his will to accomplish an even

105 greater deed, with the purpose to certify in front of everyone the mercy of the holy numen. This was, in fact, the fig tree that once stood in the garden and carried the King's order that the protoplast might not take anything from it; 110 and, since a sudden figure made him yield to the law and led him to cover his limbs, by then shameful, with its leaves, it tore him down and killed him for divine complaint; therefore, it has now, damned, lost its crown. This fig tree, which in the past had carried bad fruits and

115 leaves, made barren by Christ, teaches that $\mathrm{He}$ renews everything taking the first fruits of sin (which the devil produced, thus persuading man to trample on divine law) and freeing the mortals' hearts subjugated to it. On the other

120 hand, others believe that Christ made the tree wither to teach that he could by himself damn those who are evil, because they thought that Christ wanted to perfect those who are evil and not to punish them: "He does not annihilate man, because God himself says that He for-

125 gives everything". And he did it also for this reason: He wanted to discourage the greedy so that he, mad, would not lose himself betraying his master for money and so that he, being aware that He can also punish the sacrilegious, would, terrified, give up on this purpose. Like a doctor, guardian of men, intending to heal whoever is afflicted by an internal disease, tries at first to recognize the position of the limbs and to use the usual healing method, namely investigating every animal that has similar limbs to the human ones and, opening

135 the entrails alive, gives life to his patients through the death of the pigs, in the same way Christ, when he noticed the weakness and gullibility of his disciples, wanted to strengthen them through the example of the cursed fig tree; therefore, he, without guilt, lets the branches wither. We have said such things with the intent to report our thought, but

140 whoever tries to investigate in any way will find other interpretations, because divine deeds are like gems; however they are interpreted, they will look marvelous. 


\section{Bibliographie}

Arcari (2016): Luca Arcari, "Il "canto nuovo" di Cristo, tra Davide e Orfeo (Clem., Protr. 1, 2-5; Eus., L. Const. 14, 5)", in: Gennaro Luongo (ed.), Amicorum munera. Studi in onore di Antonio V. Nazzaro, Napoli, 41-88.

Arweiler (1998): Alexander Arweiler, Die Imitation antiker und spätantiker Literatur in der Dichtung "De spiritalis historiae gestis" des Alcimus Avitus. Mit einem Kommentar zu Avit. carm. 4,429-540 und 5,526-703, Bonn 1998 ("Untersuchungen zur antiken Literatur und Geschichte" 52).

Bartsch (1962): Hans-Werner Bartsch, "Die Verfluchung" des Feigenbaums", in: Zeitschrift für die Neutestamentliche Wissenschaft und die Kunde der Älteren Kirche 53, 256-260.

Biguzzi (1987): Giancarlo Biguzzi, "Io distruggerò questo tempio". Il tempio e il giudaismo nel vangelo di Marco, Roma.

Blaise-Chirat (1954): Albert Blaise/Henri Chirat, Dictionnaire Latin-Français des auteurs chrétiens, Turnhout.

Canali (2011): Luca Canali, Aquilino Giovenco, Il poema dei Vangeli, Milano.

Catafygiotu Topping (1978): Eva Catafygiotu Topping, “On earthquakes and fires: Romano's encomium to Justinian”, in: Byzantinische Zeitschrift 71 (1), 22-35.

Colombi (1997): Emanuela Colombi, "Paene ad verbum: gli Evangeliorum libri di Giovenco tra parafrasie commento", in: Cassiodorus 3, 9-36.

Cutino (2016-2017): Michele Cutino, “L’accomplissement de la paraphrase néotestamentaire en Occident: les In evangelia libri de Severus de Malaga", in: Michele Cutino (ed.), Poésie et Bible aux $I V^{e}-V I^{e} s$. Actes de la session scientifique de l'Assemblée générale de l'Association "Textes pour l'Histoire de l'Antiquité Tardive" Paris, École Nationale des Chartes, 8 octobre 2016. Revue des Études Tardo-Antiques 6. Supplément 4, 189-213.

Deproost (1997): Paul-Augustin Deproost, "L'épopée biblique en langue latine. Essai de définition d'un genre littéraire", in: Latomus 56, 14-39.

Dinkova-Bruun (2007): Greti Dinkova-Bruun, "Biblical Versifications from Late Antiquity to the Middle of the Thirteenth Century: History or Allegory?", in Willemien Otten and Karla Pollmann (eds.), Poetry and Exegesis in Premodern Latin Christianity, Leiden, 315-342.

Dronke (1998): Peter Dronke, "La persistenza dei miti musicali greci attraverso la letteratura mediolatina”, in: Musica e Storia 6 (1), 55-79.

Fichtner (1994): Rudolf Fichtner, Taufe und Versuchung Jesu in den Evangeliorum libri quattuor des Bibeldichters Juvencus (1, 346-408), Stuttgart und Leipzig.

Galli (2012): Giovenco. I libri dei Vangeli. Introduzione, traduzione e note a cura di F. G., Roma.

Gollwitzer-Voll (2007): Woty Gollwitzer-Voll, Christus Medicus - Heilung als Mysterium. Interpretationen eines alten Christusnamens und dessen Bedeutung in der Praktischen Theologie, Paderborn.

Green (2006): Roger P.H. Green, Latin Epics of the New Testament: Juvencus, Sedulius, Arator, Oxford.

Grosso (2004): Matteo Grosso, “L'enigma del fico senza frutti. Questioni critiche e interpretative su Mc 11,12-14.20-25”, in: Quaderni del Dipartimento di Filologia, Linguistica e Tradizione Classica "Augusto Rostagni" 3, 121-147.

Hecquet-Noti (2011): Nicole Hecquet-Noti, Avit de Vienne. Eloge consolatoire de la chasteté (sur la virginité), Paris.

Hatch (1923): William H.P. Hatch, "The Cursing of the Fig Tree”, in: Journal of the Palestine Oriental Society 3, 6-12.

Hatfield (1890): James T. Hatfield, A Study of Juvencus, Bonn.

Herzog (1975): Reinhart Herzog, Die Bibelepik der lateinischen Spätantike, München. 
Hübner (1985): Jörg Hübner, “Christus medicus. Ein Symbol des Erlösungsgeschehens und ein Modell ärztlichen Handelns”, in: Kerygma und Dogma 31, 324-335.

Huemer (1891): Iohannes Huemer, Gai Vetti Aquilini luvenci Evangeliorum libri quattuor. Recensuit et commentario critico instruxit I. H., CSEL 24, Pragae-Vindobonae-Lipsiae.

Jülicher (1938): Adolf Jülicher, Itala. Das Neue Testament in altlateinischer überlieferung nach den Handschriften, I. Matthaus- Evangelium, Berlin.

Jülicher (1940): Adolf Jülicher, Itala. Das Neue Testament in altlateinischer überlieferung nach den Handschriften, II. Marcus-Evangelium, Berlin.

Kartschoke (1975): Dieter Kartschoke, Bibeldichtung. Studien zur Geschichte der epischen Bibelparaphrase von Juvencus bis Otfrid von Weißenburg, München 1975.

Kirsch (1979): Wolfgang Kirsch, "Strukturwandel im lateinischen Epos des IV-VI Jhs.", in: Philologus 123, 38-53.

Leone (2004): Massimo Leone, Religious Conversion and Identity: The Semiotic Analysis of Texts, London and New York.

Leumann-Hofmann-Szantyr (1972): Manu Leumann, Anton Szantyr and Johann Baptist Hofmann, Lateinische Grammatik. II. Lateinische Syntax und Stilistik, München.

Luz (1997): Ulrich Luz, Das Evangelium nach Matthäus, III, Zürich.

Maltby (2002): Robert Maltby, Tibullus: Elegies. Text, Introduction and Commentary, Cambridge.

Manson (1950-1951): Thomas W. Manson, “The Cleansing of the Temple", in: The Bulletin of the John Rylands Library 33, 271-281.

McClure (1981): Judith McClure, "The biblical Epic and its Audience in Late Antiquity”, in: Papers of the Liverpool Latin Seminar 3, 1981, 305-321.

McGill (2016): Scott McGill, Juvencus' Four Books of the Gospels: Evangeliorum libri quattuor. Translated and with an Introduction and Notes. Routledge later Latin poetry, London and New York.

Milani (2002): Celestina Milani, "Gli Intineraria ad loca sancta", in: Giovanni Gobber-Celestina Milani (eds.), Tipologia dei testi e tecniche espressive. Atti del convegno, Milano, 15-16 novembre 2001, Milano, 37-46.

Mori (2013): Roberto Mori, Sedulio: tra prosa e poesia. L'Opus Paschale e il Carmen Paschale, Padova.

Murgatroyd (2002): Paul Murgatroyd, Tibullus, Elegies II, Oxford.

Nazzaro (2001): Antonio V. Nazzaro, "Poesia biblica come espressione teologica: fra Tardoantico e Altomedievo", in: Francesco Stella (ed.), La scrittura infinita. Bibbia e poesia in età medievale e umanistica, Firenze, 119-153.

Nazzaro (2006): Antonio V. Nazzaro, "Riscritture metriche di testi biblici e agiografici in cerca del genere negato", in: Auctores Nostri 4, 397-439.

Nodes (1993): Daniel J. Nodes, Doctrine and Exegesis in Biblical Latin Poetry, Leeds 1993.

Oakman (2008): Douglas E. Oakman, Jesus and the Peasants, Eugene (Matrix: The Bible in Mediterranean Context).

Panagl (2007): Victoria Panagl (ed.), Sedulius. Opera Omnia. Ex Recensione Iohannis Huemer, CSEL 10, Wien.

Pesch (1980-82): Rudolf C. Pesch, Il Vangelo di Marco, vol. II, tr. it. Brescia 1980-82.

Piscitelli (2007): Teresa Piscitelli, “La croce nell'esegesi patristica del II e III secolo", in: Boris Ulianich and Ulderico Parente (eds.), La croce. Iconografia e interpretazione: secoli I-inizio XVI. Atti del convegno internazionale di studi, Napoli, 6-11 dicembre 1999, Napoli, I, $129-152$

Poinsotte (2009): Jean-Michel Poinsotte, Commodien. Instructions. Texte établi et traduit par J.-M. P., Paris.

Reichmann (1969): Viktor Reichmann, "Feige I (Ficus carica)", in: Reallexikon für Antike und Christentum 7, 640-689 
Roberts (1985): Michael Roberts, Biblical Epic and Rhetorical Paraphrase in Late Antiquity,

Liverpool.

Rodríguez Hevia (1980): Vicente Rodríguez Hevia, “Las fórmulas de transición en Juvenco”, in:

Studia philologica Salmanticensia 5, 255-271.

Romaniuk (1975): Kazimierz Romaniuk, “Car ce n'etait pas la saisons des figues ... (Mk 11 12-14

parr.)", in: Zeitschrift für die neutestamentliche Wissenschaft 66, 277-278.

Santorelli (2011): Paola Santorelli, Aquilino Giovenco, Il poema dei Vangeli, Milano.

Smith (1960): Charles W.F. Smith, "No Time For Figs (Mc 11:12-14, 20-23)", in: Journal of Biblical Literature 79, 326-327.

Stella (2001): Francesco Stella, Poesia e teologia: l'Occidente latino tra IV e VIII secolo, Milano.

Stella (2006): Francesco Stella, “Imitazione interculturale e poetiche dell'alterità nell'epica biblica latina” in: Incontri triestini di filologia classica V. Il calamo della memoria. Trieste, 9-24.

Thraede (1960): Klaus Thraede, “Epos”, in: Reallexikon für Antike und Christentum 5, 983-1042. Weber-Gryson (20075): Robert Weber and Roger Gryson, Biblia sacra Vulgata, Stuttgart $2007^{5}$. Weber (2013): Dorothea Weber, “Medicorum pueri - Zu einer Metapher bei Augustinus”, in: Zeitschrift für Antikes Christentum 17, 125-142.

Zuliani (2005): Maurizio Zuliani, Commento al III libro degli Evangeliorum libri di Giovenco. Tesi di Dottorato, Macerata.

Zwierlein (1994): Severi Episcopi (Malacitani (?) In Evangelia libri XII: Das Trierer Fragment der Bücher VII-X. Unter Mitwirkung von Reinhart Herzog erstmalig herausgegeben und kommentiert von. Bernhard Bischoff $\dagger$ und Willy Schetter $\dagger$ bearbeitet von Otto Zwierlein, München. 